\title{
Primary Site of New Non-Melanoma Tumor Event
}

National Cancer Institute

\section{Source}

National Cancer Institute. Primary Site of New Non-Melanoma Tumor Event. NCI

Thesaurus. Code C158834.

A directive to identify the primary site to the new non-melanoma tumor event. 